\title{
ASSOCIATION OF DYSLIPIDEMIA WITH DIABETES IN PATIENTS
}

\section{WITH STROKE PATIENTS.}

\author{
DR. SWAIBA SAMAR, MBBS \\ NISHTAR HOSPITAL, MULTAN, PAKISTAN. \\ DR. ATTIA BATOOL, MBBS \\ NISHTAR HOSPITAL, MULTAN, PAKISTAN. \\ DR. TEHREEM RAFI, MBBS \\ NISHTAR HOSPITAL, MULTAN, PAKISTAN.
}

\begin{abstract}
;
Background; Stroke is a global health problem. Stroke is responsible for major disabilities in adult population, and is $2^{\text {nd }}$ leading cause of deaths all over the world. Different studies have reported dyslipidemia as major cause of stroke in different populations. Objective; To determine the frequency of dyslipidemias in patients with ischemic stroke at Nishtar Hospital Multan. Material and methods; All the cases of stroke ( $\mathrm{n}=240)$ Patients having finding on CT scan brain (plain) consistent with ischemic stroke of either sex aged less than 80 years were enrolled in this cross-sectional study from department of Medicine, Nishtar Hospital, Multan. Complete history about onset of illness, diabetes, hypertension and cardiac illness of the patients was taken. Baseline laboratory investigations including lipid profile and $\mathrm{Hb} \mathrm{A}_{1} \mathrm{c}$ were done. Results; Of these 240 study cases, 155 $(64.6 \%)$ were male patients and $85(35.4 \%)$ were female patients. Mean age of our study cases was $68.37 \pm$ 14.55 years (with minimum age was 34 years while maximum age was 79 years). Out of these 240 study cases, $138(57.5 \%)$ were from poor families, $53(22.1 \%)$ were diabetic and only 11 out of $53(20.75 \%)$ had controlled glycemic levels. Hypertension was present in $182(75.8 \%)$ of our study cases and $39(16.3 \%)$ were obese. Smoking was present in $101(42.1 \%)$, previous history of stroke was present in $35(14.6 \%)$ and $83(34.6 \%)$ were Saraikis. Mean duration of illness was $2.24 \pm 0.53$ months and $135(56.3 \%)$ had disease duration more than 1 month. Mean serum cholesterol level was $202.06 \pm 45.36 \mathrm{mg} / \mathrm{dl}$, mean serum LDL level was $91.13 \pm 10.24$ $\mathrm{mg} / \mathrm{dl}$, mean serum triglyceride level was $147.51 \pm 20.21 \mathrm{mg} / \mathrm{dl}$ and mean serum HDL level was $42.92 \pm 3.85$ $\mathrm{mg} / \mathrm{dl}$ and dyslipidemia was present in 85 (35.4\%). Diabetes was significantly associated with dyslipidemia $(\mathrm{p}=$ 0.002 ).

Conclusion; Very high frequency of dyslipidemia was noted in diabetic patients having ischemic stroke. Dyslipidemia was significantly associated with diabetes, hypertension, obesity, smoking, previous history of stroke and ethnicity. Early diagnosis followed by timely management can help reduce disease morbidity and improve clinical outcomes in these patients.
\end{abstract}

Keywords; ischemic stroke, dyslipidemia, frequency.

DOI: $10.7176 / \mathrm{JMPB} / 62-14$

Publication date: December $31^{\text {st }} 2019$

\section{Introduction;}

Stroke (Cerebrovascular accidents) is characterized by sudden development of neurological deficit. Stroke is the foremost cause of adult disability and the second leading cause of mortality worldwide ${ }^{1}$, with the burden of 15 million per year. Out of which, 5 million die and another 5 million are left incapacitated ${ }^{2-5}$. It is a huge public health problem imposing both a large disease burden and a large economic burden on the individual families and countries. Recent studies show that this problem is accelerating with the passing years. According to World Health Organization (WHO) estimates for the year 2020, stroke will remain the $2^{\text {nd }}$ leading cause of death along with ischemic heart disease both in developing and developed countries ${ }^{3,6-8}$. In addition, stroke patients in low income countries are younger than their western counterparts and consequently the burden of sustained disability in survivors is greater as well as total deaths from stroke in developing countries account for $85.5 \%$ of stroke deaths worldwide ${ }^{4}$. Ischemic Stroke occurs as a result of an obstruction within a blood vessel supplying blood to the brain. It accounts for $60-90 \%$ percent of all stroke cases in Pakistan. Hemorrhagic 
Stroke occurs when a weakened blood vessel ruptures ${ }^{9-15}$. In Pakistan, more than 75000 deaths occur due to stroke and a large number of patients are left with partial or total disabilities which puts socio economic burden on the family and society ${ }^{15}$. Risk factors for stroke include hypertension (70.8\%), diabetes (39.2\%), smoking $(26 \%)^{6}$, obesity $(18 \%)^{1}$ and cardio embolic phenomena $(25.3 \%)^{7}$. Dyslipidemia has been a known major risk factor for coronary heart disease. However more recently, it has been established as a risk factor in cerebrovascular disease ${ }^{8}$.

The purpose of this study is to determine the frequency of dyslipidemias in the patients of ischemic stroke in the targeted population.

\section{Material and Methods}

All the cases of stroke ( $\mathrm{n}=240$ ) Patients having finding on CT scan brain (plain) consistent with ischemic stroke of either sex aged less than 80 years were enrolled in this cross-sectional study from department of Medicine, Nishtar Hospital, Multan. Patients having hemorrhagic stroke, brain tumors or any other local CNS pathology like tuberculous meningitis, viral or bacterial encephalitis and multiple sclerosis documented by neuroimaging i.e. CT scan and patients having cardiac illness were excluded from our study. Informed consent was taken from each patient/attendant to participate in this study. Complete history about onset of illness, diabetes, hypertension and cardiac illness of the patients was taken. Baseline laboratory investigations including lipid profile and $\mathrm{Hb}$ $\mathrm{A}_{1} \mathrm{c}$ were done. Any one or more of the following on fasting lipid profile (12 hours of fasting)

Serum cholesterol ore than $200 \mathrm{mg} / \mathrm{dl}$

Serum LDL level more than $100 \mathrm{mg} / \mathrm{dl}$

Serum triglycerides level more than $150 \mathrm{mg} / \mathrm{dl}$

Serum HDL level less than $40 \mathrm{mg} / \mathrm{dl}^{12,13}$.

Data was entered and analyzed by computer program SPSS.

\section{Results;}

Our study included a total of 240 patients with ischemic stroke meeting inclusion criteria of our study. Of these 240 study cases, $155(64.6 \%)$ were male patients and $85(35.4 \%)$ were female patients. Mean age of our study cases was $68.37 \pm 14.55$ years (with minimum age was 34 years while maximum age was 79 years). Our study results have indicated that majority of our study cases i.e. 134 (55.8\%) belonged to the age group of $51-80$ years of age. Out of these 240 study cases, $138(57.5 \%)$ were from poor families and $102(42.5 \%)$ were from middle income families. Fifty three $(22.1 \%)$ were diabetic and only 11 out of $53(20.75 \%)$ had controlled glycemic levels. Hypertension was present in $182(75.8 \%)$ of our study cases. Mean height of our study cases was $153.67 \pm 10.91$ centimeters while mean weight was $65.49 \pm 6.46$ kilograms and mean BMI was $25.14 \pm 3.28$ $\mathrm{kg} / \mathrm{m}^{2}$ and $39(16.3 \%)$ were obese. Smoking was present in $101(42.1 \%)$, previous history of stroke was present in $35(14.6 \%)$. Mean duration of illness was $2.24 \pm 0.53$ months and $135(56.3 \%)$ had disease duration more than 1 month.

Mean serum cholesterol level was $202.06 \pm 45.36 \mathrm{mg} / \mathrm{dl}$, mean serum LDL level was $91.13 \pm 10.24 \mathrm{mg} / \mathrm{dl}$, mean serum triglyceride level was $147.51 \pm 20.21 \mathrm{mg} / \mathrm{dl}$ and mean serum HDL level was $42.92 \pm 3.85 \mathrm{mg} / \mathrm{dl} \mathrm{and}$ dyslipidemia was present in 85 (35.4\%). Association of dyslipidemia with regards to diabetes has been described in Table No. 1. 
Table No. 1

\section{Stratification of low dyslipidemia with regards to diabetes.}

$(\mathrm{n}=240)$

\begin{tabular}{|c|c|c|c|}
\hline \multirow{2}{*}{ Diabetes } & \multicolumn{2}{|c|}{ Dyslipidemia } & \multirow{2}{*}{ P - value } \\
\cline { 2 - 3 } & $\begin{array}{c}\text { Yes } \\
(\mathrm{n}=85)\end{array}$ & $\begin{array}{c}\text { No } \\
(\mathrm{n}=155)\end{array}$ & \multirow{2}{*}{$\mathbf{0 . 0 0 1}$} \\
\hline $\begin{array}{c}\text { Yes } \\
(\mathrm{n}=53)\end{array}$ & 51 & 02 & \\
\hline $\begin{array}{c}\text { No } \\
(\mathrm{n}=187)\end{array}$ & 34 & 153 \\
\hline Total & \multicolumn{2}{|c|}{$\mathbf{2 4 0}$} \\
\hline
\end{tabular}

\section{Discussion;}

Stroke is a leading cause of long-term leading cause of the death worldwide. Dyslipidemia is a major risk factor for cardiovascular diseases. Our study included a total of 240 patients with ischemic stroke meeting inclusion criteria of our study. Of these 240 study cases, $155(64.6 \%)$ were male patients and $85(35.4 \%)$ were female patients. Misirli et al ${ }^{16}$ from Turkey has also reported male gender predominance with $55 \%$ which is in compliance with our study results. A study conducted by Kumar et al ${ }^{17}$ has also reported male gender preponderance with $76 \%$ male patients and $24 \%$ female patients which is in compliance with our study results. A study conducted in Hyderabad by Shaikh et al ${ }^{18}$ has also reported male gender predominance with $73 \%$ male patients with ischemic stroke which is close to our findings. A study conducted by Khan et al ${ }^{1}$ from Karachi has reported $78 \%$ male gender preponderance in ischemic stroke which is close to our study results.

Mean age of our study cases was $68.37 \pm 14.55$ years (with minimum age was 34 years while maximum age was 79 years). Our study results have indicated that majority of our study cases i.e. 134 (55.8\%) belonged to the age group of $51-80$ years of age. Misirli et al ${ }^{16}$ from Turkey has also reported $68.7 \pm 10.9$ years mean age of the ischemic stroke patients which is close to our study results. A study conducted by Kumar et al ${ }^{17}$ has also reported $59.72 \pm 6.40$ years mean age the stroke patients which is close to our study results. A study conducted by Abid et al ${ }^{19}$ has reported similar results.

Out of these 240 study cases, 138 (57.5\%) were from poor families and $102(42.5 \%)$ were from middle income families. A study conducted by Khan et al ${ }^{1}$ from Karachi has also documented that more than $60 \%$ of stroke patients belonged to poor families which is in compliance with our study results.

Diabetes mellitus (DM) is considered as one of the important risk factors of acute ischemic stroke (AIS), which has been proved in a series of studies. The important pathogenesy behind it is atherosclerosis, which perhaps has more direct correlation with the blood lipid. As the independent risk factors for cardiovascular and cerebrovascular disease, both of the DM and blood lipid have the impact on the AIS which is accepted wildly, but the relation between the DM and lipid during the occurrence and development of AIS is unclear. Fifty three $(22.1 \%)$ were diabetic and only 11 out of $53(20.75 \%)$ had controlled glycemic levels. Hypertension was present in $182(75.8 \%)$ of our study cases. Misirli et al 16 from Turkey has also reported $71.7 \%$ hypertension while diabetes in $33.3 \%$ which is similar to our study results. A study conducted in Hyderabad by Shaikh et al ${ }^{18}$ has also reported hypertension in $52 \%$, diabetes in $24.7 \%$ which is similar to that of our study results. A study conducted by Kumar et al ${ }^{17}$ has also reported diabetes in $30 \%$ and hypertension was $51 \%$ showing compliance with that of our study results. A study conducted by Khan et al ${ }^{1}$ from Karachi has also documented $36 \%$ diabetes which is slightly higher than our findings.

Mean height of our study cases was $153.67 \pm 10.91$ centimeters while mean weight was $65.49 \pm 6.46$ kilograms and mean BMI was $25.14 \pm 3.28 \mathrm{~kg} / \mathrm{m}^{2}$ and $39(16.3 \%)$ were obese. A study conducted by Khan et al ${ }^{1}$ from Karachi has also documented mean BMI of the ischemic stroke patients was $25.57 \pm 0.68 \mathrm{~kg} / \mathrm{m}^{2}$ and obesity in $18.1 \%$. Smoking was present in 101 (42.1\%), previous history of stroke was present in $35(14.6 \%)$ and $83(34.6 \%)$ were Saraikis. Misirli et al ${ }^{16}$ from Turkey has also reported $35 \%$ smoking in these patients 
which is close to our findings. A study conducted by Kumar et al ${ }^{17}$ has also reported smoking in $36 \%$ which is close to our study results. A study conducted in Hyderabad by Shaikh et al ${ }^{18}$ has reported smoking $11.3 \%$ which is quite low than that of our findings. A study conducted by Khan et al ${ }^{1}$ from Karachi has also documented $58 \%$ smoking in patients with ischemic stroke which is close to our study results.

Mean serum cholesterol level was $202.06 \pm 45.36 \mathrm{mg} / \mathrm{dl}$, mean serum LDL level was $91.13 \pm 10.24$ $\mathrm{mg} / \mathrm{dl}$, mean serum triglyceride level was $147.51 \pm 20.21 \mathrm{mg} / \mathrm{dl}$ and mean serum HDL level was $42.92 \pm 3.85$ $\mathrm{mg} / \mathrm{dl}$ and dyslipidemia was present in $85(35.4 \%)$. Misirli et al 16 from Turkey has also reported $24 \%$ dyslipidemia which is close to our findings. A study conducted by Kumar et al ${ }^{17}$ has also reported dyslipidemia in $30 \%$ which is close to our study results. A study conducted in Hyderabad by Shaikh et al ${ }^{18}$ has also reported dyslipidemia $12 \%$ which is less than that of our findings. Abide et al has reported $37.1 \%$ dyslipidemia which is close to our study results. A study conducted by Khan et al ${ }^{1}$ from Karachi has also documented dyslidemia in $32.7 \%$ which is similar to our study results.

\section{Conclusion;}

Frequency of dyslipidemia was high among patients having ischemic stroke in our study. Dyslipidemia was significantly associated with diabetes, hypertension, obesity, smoking, previous history of stroke and ethnicity. Early diagnosis followed by timely management can help reduce disease morbidity and improve clinical outcomes in these patients.

\section{References}

1. Khan NI, Naz L, Mushtaq S, Rukh L, Ali S, Hussain Z. Ischemic stroke: Prevalence of modifiable risk factors in male and female patients in Pakistan. Pak J Pharm Sci. 2009;22(1):62-67.

2. Bashart Z, Mumtaz S, Rashid F, Raashid S, Mallam SA, Diljan A, et al. Prevalence of risk factors of ischemic stroke in a local Pakistani population. Neurosciences. 2012;17(4):357-62.

3. Khan SF, Zafar A, Malik A. Stroke in Pakistan; reality, challenges and a call for action. Pak J Neurol Sci. 2008;3:14-9.

4. Feigin VL. Stroke in developing countries: can the epidemic be stopped and outcomes improved? Lancet Neurol. 2007;6(2):94-7.

5. Khan J, Rehman A, Shah AA, Jielani A. Frequency of hypertension in stroke patients presenting at Ayub teaching hospital. J Ayub Med Coll Abbottabad. 2006;18(1):59-61.

6. Ahmed A, Usman F, Hassan A. Risk factors and pattern of stroke in Islamabad. Rawal Med J. 2009;34(1):47-50.

7. Sher K, Shah S, Kumar S. Etiological patterns of ischemic stroke in young adults. J Coll Physicians Surg Pak. 2013;23(7):472-75.

8. Goldstein LB, Adams R, Becker K, Furberg CD, Gorelick PB, Hademenose GB, et al. Primary prevention of ischemic stroke: a statement for healthcare professionals from the stroke council of the American Heart Association. Circulation. 2001;103:163.

9. Baluch UT, Kiani I, Zaib-Un-Nisa, Badshah M. Association of dyslipidemia and ischemic stroke. Ann Pak Inst Med Sci. 2008;4(3):165-67.

10. Cynthia A, Yogeesha KS, Arunchalam R. Dyslipidemia in stroke. JDMS. 2014;13:45-9.

11. Saeed E, Ali R, Jalal-Ud-Din M, Saeed A, Jadoon RJ, Moiz M. Hypercholesterolemia in patients of ischemic stroke. J Ayub Med Coll Abbottabad. 2015;27(3):637-9.

12. Buettner C, Davis RB, Leveill SG, Mittleman MA, Mukamal KJ. Prevalence of musculoskeletal pain and statin use. J Gen Intern Med. 2008;23:1182-86.

13. Khlief Y, Hayassat D, Liswi M, Jaddou H, Ajlouni K. Prevalence of myopathy in subjects on statin therapy attending the national centre for diabetes, endocrinology and genetics in Jordan. Endocrinol Metab Syndr. 2015;4:204. 
14. Hsu WC, Araneta MRG, Kanaya AM, Chiang JL, Fujimoto W. BMI cut points to identify at risk American Asian for type 2 diabetes screening. Diabetes Care. 2015;38(1):150-8.

15. Wildman RP, Gu D, Reynolds K, Duan X, He J. Appropriate body mass index and waist circumference cutoffs for categorization of overweight and central adiposity among Chinese adults. Am J Clin Nutr. 2004;80:1129-36.

16. Misirli HC, Yanar HT, Erdogan SN, Akkilic EC, Ozkan D, Bayram T, et al. Frequency of left atrial dilatation in ischemic stroke. North Clin Istanb. 2015;2(1):7-12.

17. Kumar R, Shah MI, Lakhair MA, Memon Z. Ischemic stroke; frequency of dyslipidemia and other risk factors at Tertiary Care hospital Hyderabad/ Jamshoro. Professional Med J 2016;23(8):925-931.

18. Shaikh MA, Lakhair MA, Rajput MR, Bano R, Zafarullah M, Rind S. Frequency of helicobacter pylori in Ischemic stroke. J Liaqat Uni Med Health Sci. 2011;10(3):153-56.

19. Abid N, Khan SA, Taseer IH. Frequency of hyperlipidemia in patients presenting with ischemic stroke. Pak J Med Health Sci. 2012;6(2):423-27. 